\title{
On the Electric Charge of Binary Molten Alloys*
}

\author{
By Kazuhisa Okajima** and Hiroshi Sakao**
}

\begin{abstract}
The electric charge of the molten alloys has been determined by using the TIE method and it seems that the charge exists only at surface of the alloys.

The sign of e.m.f. values obtained may be closely related to the difference between the heats of mixing measured by the e. m.f. and the calorimetric methods. This leads to the conclusion that the charge plays an important role for the difference in thermodynamic quantity between the surface and the body of the molten alloy.
\end{abstract}

(Received October 6, 1970)

\section{Introduction}

Until the last decade, most of the investigations on electromigration of metallic ions in the molten alloys were qualitative. Although the quantitative data have been reported, the accuracy of measurements is in general poor and the mechanisms of electromigration phenomena has yet to be made clear $^{(1) \sim(4)}$.

The present study was carried out so as to determine the existing state of electric charges in the molten alloys by the TIE method(5).

In a special concentration cell assembled, the binary molten alloys were employed instead of the conventional electrolyte and the e.m.f. of the cell was measured photographically by using a synchroscope.

Recently, the present authors ${ }^{(6)}$ have reported that the activity of components at the surface of a molten alloy differs from that in its body. In the present paper, special attention has been given to such a differences in thermodynamic quantity in regard to the electric charge of the molten alloys.

\section{Experimental Procedure}

The purities of metals used in the present work were : $\mathrm{Pb}, \mathrm{Sb}$ and $\mathrm{Bi}, 99.9999 \%$; $\mathrm{Cd}, 99.9$ and $99.9999 \%$; $\mathrm{Zn}, 99.999 \%$; Te, $99.99 \%$; Sn, $99.95 \%$.

The cell design employed is illustrated in Fig. 1. Three legs-cell container was made of the first-class hard glass, the tube (12 mm I.D.) of the alloy for electrolyte being somewhat broader than the two electrode tubes (10 mm I.D.). The lead wire was of tungsten, $0.8 \mathrm{~mm}$ in dia. and the e.m.f. measurements under an atmosphere of argon gas were made photographically using the synchroscope with rise time of $1 \times 10^{-6} \mathrm{sec}$ in sensitivity $2 \mathrm{mV} / \mathrm{cm}$ and $1.8 \times 10^{-7} \mathrm{sec}, 50 \mathrm{mV} / \mathrm{cm}$.

Initially, vinyl tubes were tightened by pinch cocks and then the container was placed in the nichrome winding vertical furnace. After evacuating and flushing at least five times, argon atmosphere was finally established. After heating to the desired temperature,

* This paper was presented at the Meeting of Tokai Branch of the Japan Institute of Metals, held at Nagoya on June 10, 1970.

** Department of Metallurgy, Faculty of Engineering, Nagoya University, Nagoya, Japan.

(1) P. C. Mangelsdorf : J. Chem. Phys., 30 (1959), 1170.

(2) J. D. Verhoeven and E. E. Hucke : Trans. Met. Soc. AIME, 227 (1963), 1156. the vinyl tubes were opened, about $8 \mathrm{~g}$ of the metal was thrown into the pure metal electrode, while metals for alloying, weighed accurately in the same volume as the pure metal electrode, were plunged into the alloy electrode. Then, about $15 \mathrm{~g}$ of alloying metals was thrown into the electrolyte-alloy tube. Weights of the metals differed slightly by the alloy systems and were computed from the density data published.

Fused alloys were agitated sufficiently with a tungsten wire possessing glass bead on its end. Subsequently, the tungsten wires were inserted, the vinyl tubes were

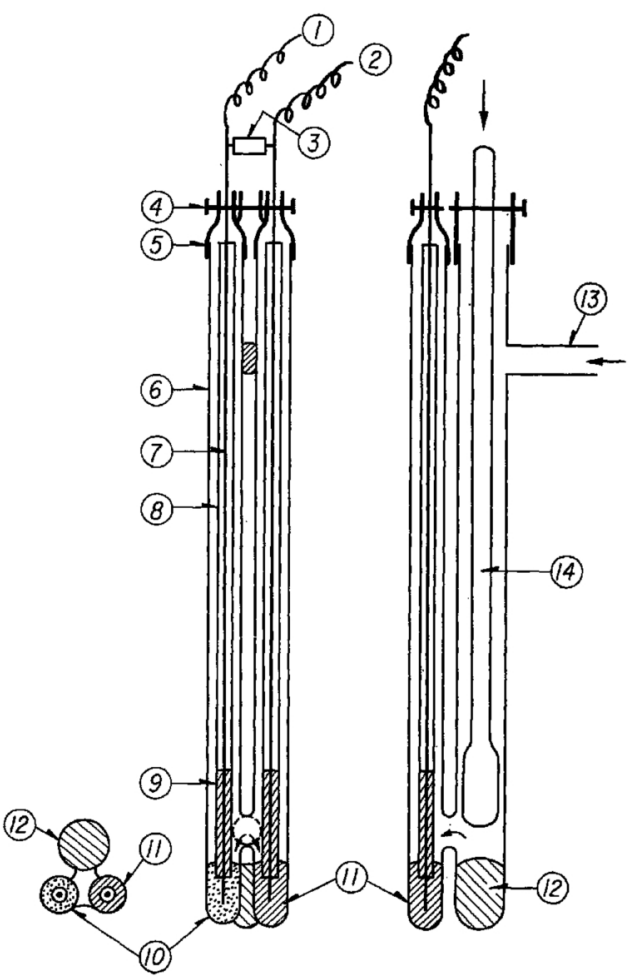

Fig. 1 Cell for e.m.f. measurement.
(1) Earth wire
(8) Porcelain lead protection sheath
(2) Signal wire
(3) Resistance, $10 \mathrm{k} \Omega$
(4) Pinch cock
(5) Vinyl tube
(6) Hard glass
(7) Tungsten lead

(3) V. A.Mikhaylov, R. A. Polovinkina, S. I. Drakin and G.M. Frolova : Phys. Met. and Metallog., 22 (1966), No. 6, 63.

(4) S. G. Epstein : Trans. Met. Soc. AIME, 236 (1966), 1123.

(5) K. Okajima and H. Sakao : Trans. JIM, 9 (1968), 47.

(6) K. Okajima and H. Sakao : Trans. JIM, 11 (1970), 180. 
closed and then the cell was maintained at the desired temperature for about $1 \mathrm{hr}$ for further homogenization.

At the start of measurement the electric power was cut off and after opening the pinch cock in the electrolyte-alloy tube, the glass rod, an end of which was blown up thickly, was inserted. As soon as the synchroscope is swept, the alloy for electrolyte was touched with the two electrodes simultaneously by pushing out it with the glass rod. The sweep curve thus produced on the synchroscope was photographed.

In the moment the electrolyte-alloy touches with the two electrodes, the cell is constituted as follows :

$$
\ominus \mathrm{Cd}|\mathrm{Cd}-\mathrm{Zn}| \mathrm{Cd}-\mathrm{Bi} \oplus
$$

If the molten alloy has the electric charge, the e.m.f. $E$ obtained from this cell may be represented by virtue of the equation,

$$
E=-R T / n F \ln a_{c d}-E_{e}
$$

where $E_{e}, a_{c d}, n, F, R$ and $T$ denote the decreased e.m.f. by electronic conduction, the activity of component cadmium, the ionic valence of metal cadmium, the Faraday constant, the gas constant and the absolute temperature, respectively.
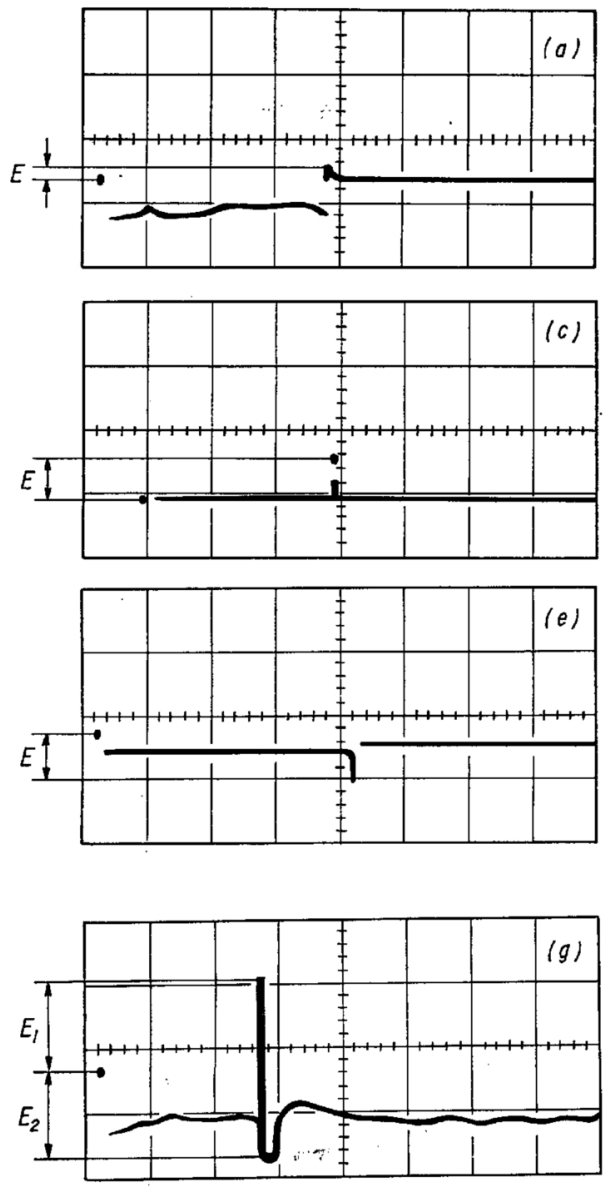

Fig. 2 Sweep curves in the various cells.

(a) $\mathrm{Pb} / \mathrm{Pb}-\mathrm{Bi} / \mathrm{Pb}-\mathrm{Sn}, N_{\mathrm{Pb}}=0.130,5 \mathrm{mV} / \mathrm{cm}, 0.5 \mathrm{sec} / \mathrm{cm}, 500^{\circ}$

(b) $\mathrm{Sn} / \mathrm{Sn}-\mathrm{Cd} / \mathrm{Sn}-\mathrm{Pb}, N_{\mathrm{Sn}}=0.250,2 \mathrm{mV} / \mathrm{cm}, 0.5 \mathrm{sec} / \mathrm{cm}, 450^{\circ}$

(c) $\mathrm{Cd} / \mathrm{Cd}-\mathrm{Bi} / \mathrm{Cd}-\mathrm{Sn}, N_{\mathrm{cd}}=0.131,10 \mathrm{mV} / \mathrm{cm}, 1 \mathrm{sec} / \mathrm{cm}, 500^{\circ}$

(d) $\mathrm{Bi} / \mathrm{Bi}-\mathrm{Sn} / \mathrm{Bi}-\mathrm{Pb}, N_{\mathrm{Bi}}=0.131,5 \mathrm{mV} / \mathrm{cm}, 1 \mathrm{sec} / \mathrm{cm}, 500^{\circ}$

(e) $\mathrm{Sn} / \mathrm{Sn}-\mathrm{Sb} / \mathrm{Sn}-\mathrm{Pb}, N_{\mathrm{Sn}}=0.250,5 \mathrm{mV} / \mathrm{cm}, 0.5 \mathrm{sec} / \mathrm{cm}, 550^{\circ}$

(f) $\mathrm{Te} / \mathrm{Te}-\mathrm{Bi} / \mathrm{Te}-\mathrm{Sb}, N_{\mathrm{Te}}=0.250,20 \mathrm{mV} / \mathrm{cm}, 0.5 \mathrm{sec} / \mathrm{cm}, 600^{\circ}$

(g) $\mathrm{Sn} / \mathrm{Sn}-\mathrm{Bi} / \mathrm{Sn}-\mathrm{Sb}, N_{\mathrm{Sn}}=0.130,5 \mathrm{mV} / \mathrm{cm}, 0.5 \mathrm{sec} / \mathrm{cm}, 600^{\circ}$

(h) $\mathrm{Sb}-\mathrm{Sn}(\mathrm{I}) / \mathrm{Sb}-\mathrm{Cd} / \mathrm{Sb}-\mathrm{Sn}(\mathrm{II}), N_{\mathrm{Sb}}(\mathrm{I})=0.500, N_{\mathrm{Sb}}(\mathrm{II})=0.200$, $5 \mathrm{mV} / \mathrm{cm}, 0.5 \mathrm{sec} / \mathrm{cm}, 500^{\circ}$
However, a quantitative evaluation seems difficult $n$ and $E_{e}$ are unknown. Consequently, in the to the lead of the alloy must become positive provided the molten alloy is itively $N_{A}=0.100-0.350$. Two runs for each e.m.f. depends on the concentration and also to check reproducibility of the sign of the e.m.f. In some alloys $\mathrm{Pb}-\mathrm{Bi}$ and $\mathrm{Cd}-\mathrm{Pb}$, the temperature dependences point of the metal, an alloy of higher concentration was put in the tube of the pure metal electrode and the e.m.f. of the concentration cells were measured using the alloy as the standard.

The measured alloy systems comprise twelve varieties,
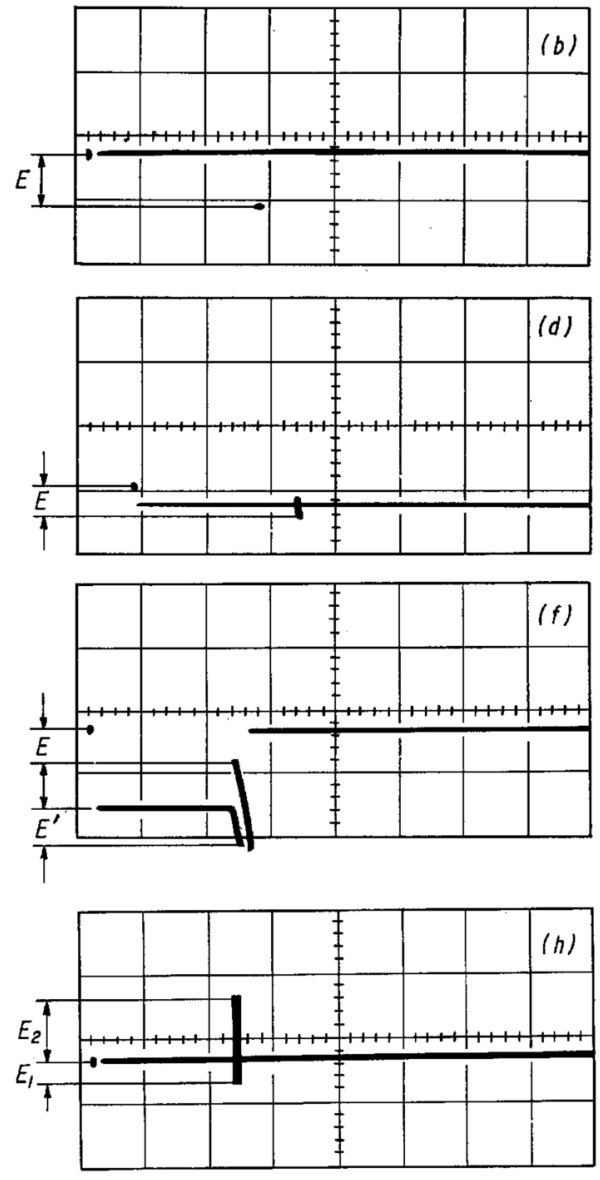
among which the system $\mathrm{Bi}-\mathrm{Te}$, known as liquid semiconductor $^{(7)}$, was taken up for determining the electronic conductivity in the cell.

\section{The Sweep Curves and the Experimental Results}

Figure 2 illustrates an example of the sweep curves. The signal and earth wires were connected to the leads of the two electrodes and immediately after the synchroscope was swept, the electrolyte-alloy was touched with the electrodes pushing out it by the glass rod. At this moment there appeared remarkable e.m.f., and this phenomenon was observed at almost all runs. From this fact, it seems safe to conclude that the charge exists only at the surface of the molten alloy. The e.m.f. value became positive or negative due to the variety of the alloys and Figs. 2 (a) and (c) are illustrations for the former and Figs. 2 (b), (d) and (e) are for the latter. As already reported ${ }^{(8)}$, the e.m.f. produces usually being based on the $E$ spot but sometimes on the $E S$ spot. This example is illustrated in Fig. $2(\mathrm{f})$, showing that $E$ is equal to $E^{\prime}$. Also, as shown in Figs. $2(\mathrm{~g})$ and $(\mathrm{h})$, the positive and the negative e.m.f. values sometimes appear at the same time. This means the coexistence of positively and negatively charged ions.

A summary of the e.m.f. obtained is given in Table 1 . The e.m.f. values, in general, are under several $\mathrm{mV}$, but these values increase with increasing temperature and decreasing alloy concentration.

The presence of the electronic conductivity must be, of course, considered in the case in which the molten

Table 1 Experimental results.

\begin{tabular}{|c|c|c|c|c|c|}
\hline \multirow{2}{*}{$\begin{array}{l}\text { Measured alloy } \\
\left(N_{A}=0.500\right)\end{array}$} & \multirow{2}{*}{ Electrode A } & \multicolumn{2}{|c|}{ Electrode B } & \multirow{2}{*}{$\mathrm{T}^{\circ} \mathrm{C}$} & \multirow{2}{*}{$E(\mathbf{m V})$} \\
\hline & & Alloy & $N_{A}$ & & \\
\hline $\mathrm{Cd}-\mathrm{Zn}$ & $\begin{array}{l}\mathrm{Cd} \\
\mathrm{Cd} \\
\mathrm{Zn} \\
\mathrm{Zn}\end{array}$ & $\begin{array}{l}\mathrm{Cd}-\mathrm{Bi} \\
\mathrm{Cd}-\mathrm{Bi} \\
\mathrm{Zn}-\mathrm{Bi} \\
\mathrm{Zn}-\mathrm{Bi}\end{array}$ & $\begin{array}{l}0.130 \\
0.250 \\
0.130 \\
0.250\end{array}$ & $\begin{array}{l}4,00 \\
400 \\
450 \\
450\end{array}$ & $\begin{array}{l}0.78 \\
0.53 \\
2.65 \\
1.93\end{array}$ \\
\hline $\mathrm{Zn-Sn}$ & $\begin{array}{l}\mathrm{Zn} \\
\mathrm{Zn} \\
\mathrm{Sn} \\
\mathrm{Sn}\end{array}$ & $\begin{array}{l}\mathrm{Zn}-\mathrm{Cd} \\
\mathrm{Zn}-\mathrm{Cd} \\
\mathrm{Sn}-\mathrm{Bi} \\
\mathrm{Sn}-\mathrm{Cd}\end{array}$ & $\begin{array}{l}0.130 \\
0.250 \\
0.130 \\
0.130\end{array}$ & $\begin{array}{l}450 \\
450 \\
450 \\
450\end{array}$ & $\begin{array}{l}1.63 \\
1.44 \\
2.32 \\
2.47\end{array}$ \\
\hline $\mathrm{Pb}-\mathrm{Bi}$ & $\begin{array}{l}\mathrm{Pb} \\
\mathrm{Pb} \\
\mathrm{Bi} \\
\mathrm{Bi}\end{array}$ & $\begin{array}{l}\mathrm{Pb}-\mathrm{Sn} \\
\mathrm{Pb}-\mathrm{Sn} \\
\mathrm{Bi}-\mathrm{Sn} \\
\mathrm{Bi}-\mathrm{Sn}\end{array}$ & $\begin{array}{l}0.130 \\
0.250 \\
0.130 \\
0.130\end{array}$ & $\begin{array}{l}500 \\
500 \\
500 \\
600\end{array}$ & $\begin{array}{l}0.88 \\
0.59 \\
0.56 \\
3.91\end{array}$ \\
\hline $\mathrm{Pb}-\mathrm{Sn}$ & $\begin{array}{l}\mathrm{Pb} \\
\mathrm{Pb}\end{array}$ & $\begin{array}{l}\mathrm{Pb}-\mathrm{Bi} \\
\mathrm{Pb}-\mathrm{Bi}\end{array}$ & $\begin{array}{l}0.130 \\
0.250\end{array}$ & $\begin{array}{l}500 \\
500\end{array}$ & $\begin{array}{l}1.61 \\
0.76\end{array}$ \\
\hline $\mathrm{Pb}-\mathrm{Sb}$ & $\begin{array}{l}\mathrm{Pb} \\
\mathrm{Pb}\end{array}$ & $\begin{array}{l}\mathrm{Pb}-\mathrm{Bi} \\
\mathrm{Pb}-\mathrm{Bi}\end{array}$ & $\begin{array}{l}0.130 \\
0.250\end{array}$ & $\begin{array}{l}550 \\
550\end{array}$ & $\begin{array}{l}1.83 \\
1.52\end{array}$ \\
\hline Cd-Sn & $\begin{array}{l}\text { Cd } \\
\text { Cd } \\
\text { Sn } \\
\text { Sn }\end{array}$ & $\begin{array}{l}\mathrm{Cd}-\mathrm{Pb} \\
\mathrm{Cd}-\mathrm{Pb} \\
\mathrm{Sn}-\mathrm{Pb} \\
\mathrm{Sn}-\mathrm{Pb}\end{array}$ & $\begin{array}{l}0.130 \\
0.180 \\
0.130 \\
0.250\end{array}$ & $\begin{array}{l}450 \\
450 \\
450 \\
450\end{array}$ & $\begin{array}{l}-1.12 \\
-0.87 \\
-1.61 \\
-1.40\end{array}$ \\
\hline $\mathrm{Cd}-\mathrm{Pb}$ & $\begin{array}{l}\mathrm{Cd} \\
\mathrm{Cd} \\
\mathrm{Pb} \\
\mathrm{Pb}\end{array}$ & $\begin{array}{l}\mathrm{Cd}-\mathrm{Sn} \\
\mathrm{Cd}-\mathrm{Sn} \\
\mathrm{Pb}-\mathrm{Sn} \\
\mathrm{Pb}-\mathrm{Sn}\end{array}$ & $\begin{array}{l}0.130 \\
0.250 \\
0.130 \\
0.130\end{array}$ & $\begin{array}{l}400 \\
400 \\
400 \\
500\end{array}$ & $\begin{array}{l}-0.54 \\
-0.47 \\
-0.39 \\
-1.93\end{array}$ \\
\hline $\mathrm{Bi}-\mathrm{Sn}$ & $\begin{array}{l}\mathrm{Bi} \\
\mathrm{Bi} \\
\mathrm{Sn} \\
\mathrm{Sn}\end{array}$ & $\begin{array}{l}\mathrm{Bi}-\mathrm{Pb} \\
\mathrm{Bi}-\mathrm{Pb} \\
\mathrm{Sn}-\mathrm{Sb} \\
\mathrm{Sn}-\mathrm{Sb}\end{array}$ & $\begin{array}{l}0.131 \\
0.250 \\
0.130 \\
0.176\end{array}$ & $\begin{array}{l}500 \\
500 \\
600 \\
600\end{array}$ & $\begin{array}{l}-2.21 \\
-1.14 \\
-6.53(7.14) \\
-6.31\end{array}$ \\
\hline $\mathrm{Cd}-\mathrm{Bi}$ & $\begin{array}{l}\mathrm{Cd} \\
\mathbf{C d} \\
\mathbf{B i} \\
\mathbf{B i}\end{array}$ & $\begin{array}{l}\mathrm{Cd}-\mathrm{Sn} \\
\mathrm{Cd}-\mathrm{Sn} \\
\mathrm{Bi}-\mathrm{Pb} \\
\mathrm{Bi}-\mathrm{Pb}\end{array}$ & $\begin{array}{l}0.130 \\
0.250 \\
0.180 \\
0.250\end{array}$ & $\begin{array}{l}500 \\
500 \\
500 \\
500\end{array}$ & $\begin{array}{r}6.85 \\
5.15 \\
-2.46 \\
-2.35\end{array}$ \\
\hline $\mathrm{Sn}-\mathrm{Sb}$ & $\begin{array}{c}\mathrm{Sn} \\
\mathrm{Sn} \\
\mathrm{Sb}-\mathrm{Pb}\left(N_{\mathrm{Sb}}=0.6\right) \\
\mathrm{Sb}-\mathrm{Pb}\left(N_{\mathrm{Sb}}=0.6\right)\end{array}$ & $\begin{array}{l}\mathrm{Sn}-\mathrm{Pb} \\
\mathrm{Sn}-\mathrm{Pb} \\
\mathrm{Sb}-\mathrm{Pb} \\
\mathrm{Sb}-\mathrm{Pb}\end{array}$ & $\begin{array}{l}0.130 \\
0.250 \\
0.150 \\
0.250\end{array}$ & $\begin{array}{l}550 \\
550 \\
550 \\
550\end{array}$ & $\begin{array}{r}-5.73 \\
-3.67 \\
5.39 \\
2.46\end{array}$ \\
\hline $\mathrm{Cd}-\mathrm{Sb}$ & $\begin{array}{c}\mathrm{Cd} \\
\mathrm{Cd} \\
\mathrm{Sb}-\mathrm{Sn}\left(N_{\mathrm{Sb}}=0.5\right) \\
\mathrm{Sb}-\mathrm{Sn}\left(N_{\mathrm{Sb}}=0.5\right)\end{array}$ & $\begin{array}{l}\text { Cd-Sn } \\
\text { Cd-Sn } \\
\text { Sb-Sn } \\
\text { Sb-Sn }\end{array}$ & $\begin{array}{l}0.131 \\
0.325 \\
0.100 \\
0.200\end{array}$ & $\begin{array}{l}500 \\
500 \\
500 \\
500\end{array}$ & $\begin{array}{c}3.28 \\
1.91 \\
-2.58 \\
-1.50(5.03)\end{array}$ \\
\hline $\mathrm{Bi}-\mathrm{Te}$ & $\begin{array}{l}\mathrm{Bi} \\
\mathrm{Bi} \\
\mathrm{Te} \\
\mathrm{Te}\end{array}$ & $\begin{array}{l}\mathrm{Bi}-\mathrm{Sn} \\
\mathrm{Bi}-\mathrm{Sn} \\
\mathrm{Te}-\mathrm{Sb} \\
\mathrm{Te}-\mathrm{Sb}\end{array}$ & $\begin{array}{l}0.130 \\
0.250 \\
0.250 \\
0.350\end{array}$ & $\begin{array}{l}600 \\
600 \\
600 \\
600\end{array}$ & $\begin{array}{c}14.99(-16.76) \\
9.11(-10.77) \\
-10.65 \\
-6.34\end{array}$ \\
\hline
\end{tabular}

(7) Y. Nakamura : Bull. Japan Inst. Metals, 8 (1969), 610.

(8) K. Okajima and H. Sakao : Trans. JIM, 9 (1968), 330. 
alloys were employed instead of the electrolyte. Accordingly, measurements of the system $\mathrm{Bi}-\mathrm{Te}$ was carried out to determine the ratio of the electronic conductance to ionic one. As may be known as the semi-conductor, the obtained e.m.f. values became comparatively large. From the fact that the activity of bismuth in the system $\mathrm{Bi}-\mathrm{Te}^{(9)}$ is small, the e.m.f. obtained by an usual method must, in general, become large regardless of the electrolyte used. The measured e.m.f. in the present work becomes about one-tenth compared with $E=120.16 \mathrm{mV}$ at $N_{\mathrm{Bi}}=0.15$ which has been measured using the normal electrolyte of $\mathrm{Bi}^{+3}$ ion. Because the valence in charge is unknown, an exact comparison becomes difficult, but it is certain that the part of the electronic conductance is very large.

In the other systems, it is noteworthy that the part of the electronic conductance has a tendency analogous to the system $\mathrm{Bi}-\mathrm{Te}$ due to its comparatively large activities though e.m.f. values are small.

Although a slight time difference in contact of the electrolyte-alloy with both electrodes can be considered, this may be assumed to have virtually no effect upon the measured values in view of the reproducibility of a number of data.
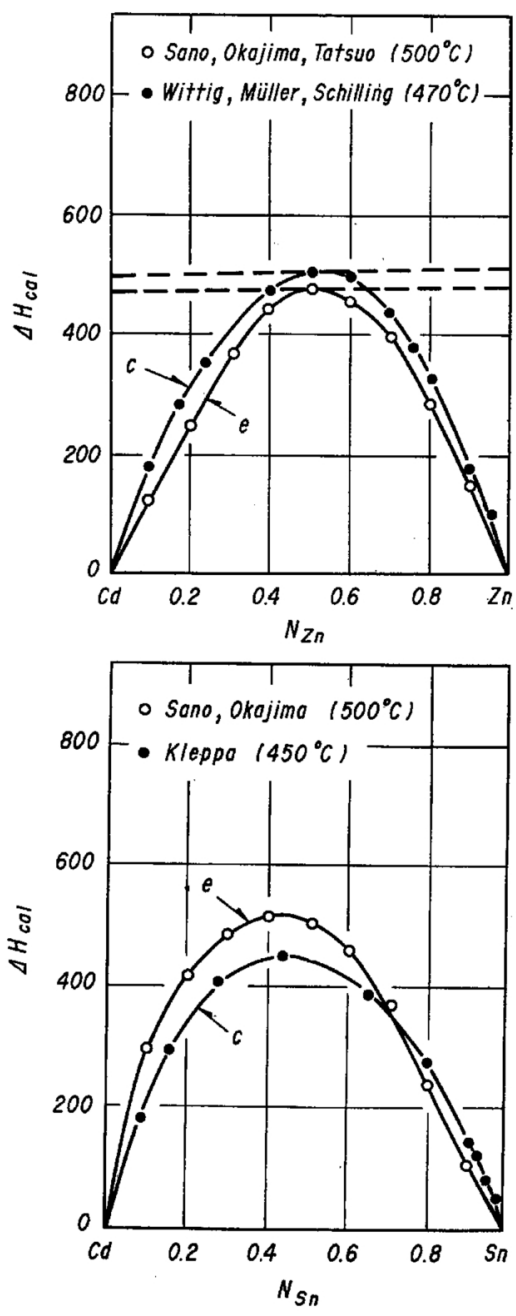

\section{On the Thermodynamic Quantities at the Surface and in the Body of the Molten Alloys}

Although the difference between the both activities at the surface and in the body of molten alloy may be attributed to different metallic binding forces, knowledge of the role of the charge existing at the surface seems to be important in recognizing the true meaning of the phenomenon.

The difference between the thermodynamic quantities at the surface and in the body can be measured by both the e.m.f. and calorimetric methods. Consequently, when the present results are compared with the difference in heats of mixing measured by the both methods, if there is a close relation between the two, these phenomena can be explained by the charge at the alloy surfaces.

Figure 3 shows typical examples of the comparison in the heats of mixing from published data determined by the e.m.f. and calorimetric methods.

It is evident that there are some differences in the two sets of data determined by both methods, especially in the Sb-system.
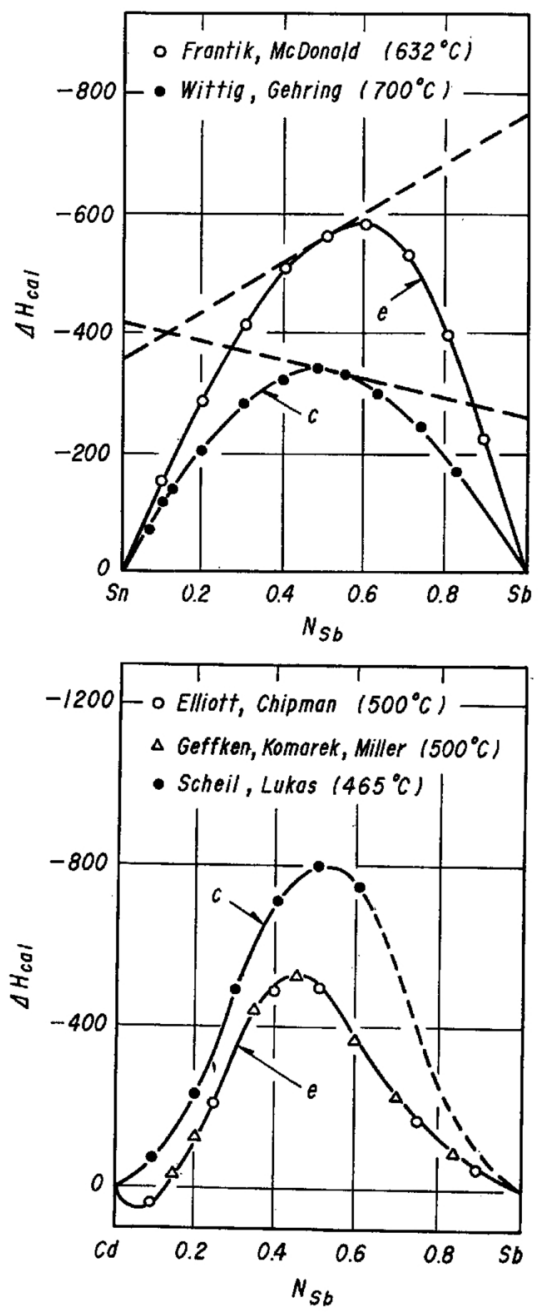

Fig. 3 Comparison between the heats of mixing by e.m.f. and calorimetric methods. (c : calorimetric method, e : e.m.f. method) 
In addition, significant discrepancies in the heats of mixing by the different methods have also been observed in the systems $\mathrm{In}-\mathrm{Sb}, \mathrm{In}-\mathrm{Bi}^{(27)}, \mathrm{Al}-\mathrm{Ga}$ and $\mathrm{Al}-\mathrm{Zn}^{(28)}$.

In short, it can be concluded that heats of mixing by the both methods do not agree with each other, suggesting an essential difference between the two.

The comparison of the difference in the heats of mixing with the data measured in the present study is possible only for a partial quantity at $N_{A}=0.5$. When the difference between the partial heats of mixing becomes the same sign for both the components as shown in the system $\mathrm{Cd}-\mathrm{Zn}$, however, it is possible to compare them by integral heats of mixing, since tangents drawn into curves at the points corresponding to the $N_{A}=0.5$ do not cross. On the other hand, in the system $\mathrm{Sn}-\mathrm{Sb}$, in which both tangents cross each other, the differences between the partial heats of mixing for both the components become opposite in sign. Table 2, in which a comparison between the measured e.m.f. and $\Delta \bar{H}_{c}-\Delta \bar{H}_{e}$ is given, shows a satisfactory agreement between the signs. Deviations of the activity ${ }^{(29)}$ from Raoult's law seem, however, to have no relation with the sign of the e.m.f. values.

The thermodynamic quantity measured by the e.m.f. method may be related to phenomena occurring at alloy/ electrolyte surfaces of separation, and the calorimetric method to the interior phenomena of the alloy. Consequently, the difference between the heats of mixing measured by the both methods may be related to atomic structures at the surface and in the body in the molten alloy.

If the e.m.f. measured is positive, the charge is assumed to be $+n$ valence, and if negative, it would be $-n$ valence. From Table 2 it is evident that the existence of $+n$ valence ion plays an exothermic part on mixing of the constituent metals, while $-n$

Table 2 Comparison between the measured e.m.f. and the difference of heats of mixing by e.m.f. and calorimetric methods.

\begin{tabular}{|c|c|c|c|c|c|c|}
\hline \multicolumn{2}{|c|}{ Alloy } & \multirow{2}{*}{$\begin{array}{l}\text { Deviation of } \\
\text { activity from } \\
\text { Raoult's law }\end{array}$} & \multirow{2}{*}{$\begin{array}{l}\text { Sign of } \\
\text { e.m.f. }\end{array}$} & \multirow{2}{*}{$\Delta \bar{H}_{c}-\Delta \bar{H}_{e}$} & \multicolumn{2}{|c|}{ References } \\
\hline System & Component & & & & $\Delta H_{c}$ & $\Delta H_{e}$ \\
\hline $\mathrm{Cd}-\mathrm{Zn}$ & $\begin{array}{l}\mathrm{Cd} \\
\mathrm{Zn}\end{array}$ & $\stackrel{\mathrm{P}}{\mathrm{P}}$ & $\begin{array}{l}+ \\
+\end{array}$ & $\begin{array}{l}+ \\
+\end{array}$ & Wittig, Müller, Schilling ${ }^{(10)}$ & Sano, Okajima, Tatsuo ${ }^{(17)}$ \\
\hline $\mathrm{Zn}-\mathrm{Sn}$ & $\begin{array}{l}\mathrm{Zn} \\
\mathrm{Sn}\end{array}$ & $\stackrel{P}{P}$ & $\begin{array}{l}+ \\
+\end{array}$ & $\begin{array}{l}+ \\
+\end{array}$ & Kleppa ${ }^{(11)}$ & Sano, Okajima, Tatsuo $(17)$ \\
\hline $\mathrm{Pb}-\mathrm{Bi}$ & $\begin{array}{l}\mathrm{Pb} \\
\mathbf{B i}\end{array}$ & $\underset{\mathbf{N}}{\mathbf{N}}$ & + & + & $\begin{array}{l}\text { Wittig, Huber } \\
\text { Kleppa }^{(12)}\end{array}$ & Strickler, Seltz ${ }^{(18)}$ \\
\hline $\mathrm{Pb}-\mathrm{Sn}$ & $\mathrm{Pb}$ & $\mathbf{P}$ & + & + & Kleppa ${ }^{(13)}$ & Elliott, Chipman ${ }^{(19)}$ \\
\hline $\mathrm{Pb}-\mathrm{Sb}$ & $\mathrm{Pb}$ & $\mathbf{N}$ & + & + & Yazawa, Kawashima, Itagaki (14) & Seltz, DeWitt ${ }^{(20)}$ \\
\hline $\mathrm{Cd}-\mathrm{Sn}$ & $\begin{array}{l}\text { Cd } \\
\text { Sn }\end{array}$ & $\stackrel{\mathrm{P}}{\mathrm{P}}$ & $\overline{-}$ & $\overline{-}$ & Kleppa ${ }^{(11)}$ & Sano, Okajima ${ }^{(21)}$ \\
\hline $\mathrm{Cd}-\mathrm{Pb}$ & $\begin{array}{l}\mathrm{Cd} \\
\mathrm{Pb}\end{array}$ & $\underset{\mathrm{P}}{\mathrm{P}}$ & $\overline{-}$ & $\overline{-}$ & Kleppa ${ }^{(11)}$ & Elliott, Chipman ${ }^{(22)}$ \\
\hline $\mathrm{Bi}-\mathrm{Sn}$ & $\begin{array}{l}\mathrm{Bi} \\
\mathrm{Sn}\end{array}$ & $\stackrel{\mathrm{P}}{\mathrm{P}}$ & $\underline{-}$ & - & Wittig, Huber ${ }^{(12)}$ & Seltz, Dunkerley (23) \\
\hline $\mathrm{Cd}-\mathrm{Bi}$ & $\underset{\mathrm{Bi}}{\mathrm{Cd}}$ & $\begin{array}{l}\mathbf{N}(P) \\
\mathbf{N}(\mathrm{P})\end{array}$ & \pm & \pm & Wittig, Müller, Schilling ${ }^{(10)}$ & Nikol'skaya, Gerassimov (24) \\
\hline $\mathrm{Sn}-\mathrm{Sb}$ & $\begin{array}{l}\mathrm{Sn} \\
\mathrm{Sb}\end{array}$ & $\underset{\mathbf{N}}{\mathbf{N}}$ & $\overline{+}$ & $\overline{+}$ & Wittig, Gehring ${ }^{(15)}$ & Frantik, McDonald ${ }^{(25)}$ \\
\hline $\mathrm{Cd}-\mathrm{Sb}$ & $\begin{array}{l}\mathrm{Cd} \\
\mathrm{Sb}\end{array}$ & $\stackrel{\mathbf{N}}{\mathbf{N}}$ & \pm & \pm & Scheil, Lukas ${ }^{(16)}$ & $\begin{array}{l}\text { Elliott, Chipman }{ }^{(22)} \\
\text { Geffken, Komarek, Miller }{ }^{(26)}\end{array}$ \\
\hline
\end{tabular}

(10) F.E. Wittig, E. Müller and W.Schilling: Z. Elektrochem., $62(1958), 529$

(11) O. J. Kleppa : J. Phys. Chem., 59 (1955), 354.

(12) F. E. Wittig and F. Huber : Z. Phys. Chem., 18 (1958), 330.

(13) O. J. Kleppa : J. Phys. Chem., 59 (1955), 175.

(14) A. Yazawa, T. Kawashima and K. Itagaki : J. Japan Inst. Metals, 32 (1968), 1288.

(15) F.E.Wittig and E.Gehring: Berich. Bunsenges. Physik. Chem., 71 (1967), 372

(16) E. Scheil and H. L. Lukas : Z. Metallk., 52 (1961), 417.

(17) K. Sano, K. Okajima and S. Tatsuo : Mem. Fac. Eng. Nagoya Univ., 5 (1953), 299.

(18) H.S. Strickler and H. Seltz : J. Amer. Chem. Soc., 58 (1936), 2084

(19) J. F. Elliott and J. Chipman : J. Amer. Chem. Soc., 73 (1951), 2682 .

(20) H. Seltz and B.J. DeWitt : J. Amer. Chem. Soc., 61 (1939), 2594 .
(21) K. Sano and K. Okajima : Mem. Fac. Eng. Nagoya Univ., 5 (1953), 88.

(22) J. F. Elliott and J. Chipman : Trans. Faraday Soc., 47 (1951), 138.

(23) H. Seltz and F. J. Dunkerley : J. Amer. Chem. Soc., 64 (1942), 1392.

(24) A. V. Nikol'skaya and Ya I. Gerassimov : Zhur. Fiz. Khim., 28 (1954), 713.

(25) R. O. Frantik and H. J. McDonald : Trans. Electrochem. Soc., 88 (1945), 243.

(26) R. Geffken, K. L. Komarek and E. Miller : Trans. Met. Soc. AIME, 239 (1967), 1151.

(27) H. Hoshino, Y. Nakamura, M. Shimoji and K. Niwa : Ber. Bunsenges. Physik. Chem., 69 (1965), 114.

(28) B. Predel and U. Schallner : Z. Metallk., 60 (1969), 869.

(29) R. Hultgren, R. L. Orr, P.D. Anderson and K. K. Kelley : Selected Values of Thermodynamic Properties of Metals and Alloys, John Wiley and Sons, New York, (1963), p. 331. 
valence ion is endothermic.

It has been reported ${ }^{(30)}$ that in the system $\mathrm{Cd}-\mathrm{Sb}$, whose phase diagram ${ }^{(31)}$ has an intermetallic compound, remarkable maximums of the reduced resistivity and the excess stability occur near its composition. It may be "concluded that a compound-like bond still exists in the molten alloy to a certain extent. As exceptional cases, there are systems showing the electric resistance and the excess stability similar to the system $\mathrm{Cd}-\mathrm{Sb}$, though eutectic. This is the case for the system $\mathrm{Cd}-\mathrm{Bi}^{(30)(32)}$ and may be assumed to be in the atomic bonding state similar to the system Cd-Sb in the molten state. That is, the binding force between unlike atoms as $\mathrm{Cd}-\mathrm{Sb}$ and $\mathrm{Cd}-\mathrm{Bi}$, must be stronger. In the system $\mathrm{Pb}-\mathrm{Bi}^{(33)}$, such a phenomenon can be observed for a range of mole fractions of bismuth 0.1 to 0.4 .

An understanding of the results described above leads to the conclusion that the charge at the surface of the molten alloys plays a significant role for the difference of thermodynamic quantities at the surface and in the body. However, since there are some uncertainties, this conclusion must be verified by further experiments.

Next, what kind of the charge exists at the surface of the molten alloys is considered.

For the component $\mathrm{Bi}$ of the system $\mathrm{Bi}-\mathrm{Te}$, the e.m.f. values became both positive and negative. This means the existence of $\mathrm{Bi}^{+n}$ and $\mathrm{Bi}^{-n \prime}$ ions with opposite charges, and the presence of an intermetallic compound in its phase diagram ${ }^{(31)}$, with a strong attractive force between the unlike atoms, suggests a quasi-salt like bond $\left(\mathrm{Bi}^{+n} \mathrm{Te}^{-m}\right)$. Therefore, at the surface of the molten alloy, three varieties of $\mathrm{Bi}^{-n \prime}, \mathrm{Te}^{-m \prime}$ and $\left(\mathrm{Bi}^{+n} \mathrm{Te}^{-m}\right)$ may be assumed to coexist. For lack of the knowledge of $n^{\prime}$, $m^{\prime}, n$ and $m$, the ion which produces the e.m.f. is hardly distinguishable and the uncertainty about this point cannot be avoided.

The above phenomenon is found in the component $\mathrm{Sb}$ of the system $\mathrm{Cd}-\mathrm{Sb}$, which possesses an intermetallic compound in the phase diagram and also in the component $\mathrm{Sn}$ of the eutectic system $\mathrm{Bi}-\mathrm{Sn}$. Although data have separately been obtained, the component $\mathrm{Bi}$ in the system $\mathrm{Cd}-\mathrm{Bi}$ and $\mathrm{Sb}$ in the system $\mathrm{Sn}-\mathrm{Sb}$ show similar behavior.

(30) J. L. Tomlinson and B. D. Lichter : Metallurg. Trans., $1(1970), 305$.

(31) M. Hansen : Constitution of Binary Alloys, McGraw-Hill, New York, (1958), p. 337, 339, 437.

(32) J. L. Tomlinson and B. D. Lichter : Trans. Met. Soc. AIME, 245 (1969), 2261.

(33) A. Roll and J. K. Biswas : Z. Metallk., 55 (1964), 794.
In the system $\mathrm{Bi}-\mathrm{Sn}$, in which the intermediate phase $^{(31)}$ of $\mathrm{SnBi}$ is said to produce under high pressure, the existence of $\mathrm{Sn}^{+n} \mathrm{Bi}^{-m}$ seems possible in the molten alloy even if the amount is small.

Then, discussion will be made of the role of the charge in the molten alloy for the construction of the phase diagram.

The e.m.f. values of the system $\mathrm{Cd}-\mathrm{Zn}$ showed the same signs for both components. Therefore, it is assumed that when the molten alloy of this system solidifies, like ions repel each other and the system becomes eutectic by separating into two phases. The eutectic systems $\mathrm{Cd}-\mathrm{Pb}$ and $\mathrm{Zn}-\mathrm{Sn}$ may also be interpreted due to repulsion by like ions. On the other hand, in the system $\mathrm{Cd}-\mathrm{Sb}$ having the intermetallic compound, dissolution of ion $\mathrm{Cd}^{+n}$ or $\mathrm{Sb}^{+m}$ into the quasi-salt like bond $\left(\mathrm{Cd}^{+n} \mathrm{Sb}^{-m}\right)$ leads to the formation of the charged intermetallic phase in the solidification and then the repulsion of the like ions seems to form its phase diagram. In a special system such as $\mathrm{Cd}-\mathrm{Bi}$, in which the bond by unlike atoms is strong in the molten state but becomes easily an eutectic system, dissociation of the bond $\left(\mathrm{Cd}^{+} \mathrm{Bi}^{-}\right)$in the solidification must be considered.

\section{Conclusion}

By applying the TIE method, investigations as to whether e.m.f. takes place in a special concentration cell using a binary molten alloy instead of the electrolyte have been carried out. It is shown that the charge seems to exist only at the surface of the molten alloys.

The e.m.f. values are, in general, reduced to less than several $\mathrm{mV}$ because of the remarkable large electronic conductivity. The e.m.f. values become larger with increasing temperature and decreasing alloy concentration.

Although there are some exceptions, the sign of e.m.f. values for both components are, in general, the same in the alloys of the eutectic system, while the alloy of the intermetallic compound become both positive and negative. The sign of the e.m.f. values can be closely related to the difference between the heats of mixing measured by the e.m.f. and the calorimetric methods. This fact leads to the conclusion that the charge at the alloy surface plays a significant role for the difference between the thermodynamic quantities at the surface and in the body of the molten alloy. Also, the construction of the phase diagram seems to be related to this charge. 